Abstracta Iranicacta Iranica

Revue bibliographique pour le domaine irano-aryen

Volume 32-33 | 2013

Comptes rendus des publications de 2009-2010

\title{
C. Zanier. Setaioli italiani in Asia : Imprenditori della seta in Asia Centrale (1859-1871)
}

\section{Angelo-Michele Piemontese}

\section{OpenEdition}

1 Journals

Édition électronique

URL : http://journals.openedition.org/abstractairanica/40696

DOI : 10.4000/abstractairanica.40696

ISSN : 1961-960X

Éditeur :

CNRS (UMR 7528 Mondes iraniens et indiens), Éditions de l'IFRI

Édition imprimée

Date de publication : 1 décembre 2013

ISSN : 0240-8910

Référence électronique

Angelo-Michele Piemontese, « C. Zanier. Setaioli italiani in Asia : Imprenditori della seta in Asia Centrale (1859-1871) », Abstracta Iranica [En ligne], Volume 32-33 | 2013, document 264, mis en ligne le 01 juillet 2016, consulté le 26 septembre 2020. URL : http://journals.openedition.org/abstractairanica/40696 ; DOI : https://doi.org/10.4000/abstractairanica.40696

Ce document a été généré automatiquement le 26 septembre 2020.

Tous droits réservés 
C. Zanier. Setaioli italiani in Asia : Imprenditori della seta in Asia Centrale (1859-1871)

Angelo-Michele Piemontese

\section{RÉFÉRENCE}

C. Zanier. Setaioli italiani in Asia : Imprenditori della seta in Asia Centrale (1859-1871). Padova, Coop. Libraria Editrice Università di Padova, 2008, 541 p.

1 L'A. a traité l'histoire du commerce italien et européen de la soie en Asie Centrale, soit de la Chine à l'Iran (1859-1871).

\section{AUTEURS}

ANGELO-MICHELE PIEMONTESE

Università la Sapienza, Rome 